\title{
Studies on the Friction Mechanism of Silica-Filled and Carbon Black-Filled SBRs, Part 3. The Friction of Carbon Black-Filled and Silica-Filled SBR Blends
}

Naoya Amino, (Yokohama Rubber Co., Ltd., 2-1 Oiwake, Hiratsuka, Kanagawa 254-8601, Japan), Yoshitaka Uchiyama, Tomoaki Iwai, and Masato Maeda (Department of Mechanical Systems Engineering, Kanazawa University, 2-4020, Kodatsuno, Kanazawa, Ishikawa 920-8667, Japan)

Tire tread compounds usually consist of polymer blends. In this paper the friction for immiscible SBR blends which consist of two different SBRs having different glass transition temperatures of $-51{ }^{\circ} \mathrm{C}$ and $-6{ }^{\circ} \mathrm{C}$ are investigated. The effects of the blend ratio of these two SBRs and the added fillers such as carbon black and silica on the friction are also investigated. The friction forces are measured when rubber specimens are rubbed against dry or wet metal gauze. The friction force-sliding speed curves for the SBR blends are related to their storage modulus $E^{\prime}$, loss tangent $\tan \delta$, contact area $A$ and shear strength $s$.

The adhesion component of the friction for each SBR blend shows a peak at the sliding speed range examined. As the blend ratio of the SBR having higher $T_{g}$ of $-6{ }^{\circ} \mathrm{C}$ is raised, the peak value is lowered and the peak shifts to lower sliding speed. The adhesion component of the friction for silica-filled SBR blends is higher than that of carbon black-filled SBR blends. These trends are also shown when rubber specimens are rubbed against the wet metal gauze. On the other hand, the hysteresis component of friction is raised wnen the blend ratio of the SBRs having higher $T_{g}$ is increased.

(Received on June 22, 2001)

(Accepted on August 16, 2001)

Key Word : Friction, Adhesion, Hysteresis, Viscoelastic property, Silica-filled SBR, Carbon black-filled SBR, Polymer blend

\section{1. 緒 言}

前報1)において，ガラス転移温度 $T_{g}$ の異なる 3 種類の SBR と金網との摩擦試験を実施し， $T_{g}$ の違いによって摩 擦の凝着の項とヒステリシスの項がそれぞれどのように変 化するかを調べた。この結果, 摩擦力 $F$ は, 接触面積 $A$, ゴムのせん断強さ $s$, 貯蔵弾性率 $E$, 損失正接 $\tan \delta に よ り$ 表すことができた，本報告では， $T_{g}$ の異なる相溶しない 2 種類のSBRをブレンドすることによって摩擦の凝着の項 とヒステリシスの項がそれぞれどのように変化するかを調 べた結果について報告する.

タイヤトレッド用ゴムでは, いくうかの性能を同時に満 足させるために，複数のゴムをブレンドして使用する場合 が多い.タイヤトレッドゴムの摩擦特性を調べるために, ゴム試料としてブレンドゴムを用いたいくつかの報告 ${ }^{2-6)}$ があり，また，ブレンドゴムの粘弾性特性と摩擦力を対比

\footnotetext{
†「シリカ配合およびカーボン配合 SBRの摩擦機構に関する研究(第 3 報」とする.

$* 1$ 横浜ゴム株)( $254-8601$ 平塚市追分 2-1)

*2 金沢大学工学部 ( ₹ 920-8667 金沢市小立野 2-40-20)
}

させた報告 7)8) もある.しかし，摩擦の凝着の項に注目し た研究はほとんど報告されていない.

そこで，本研究では，乾燥面拈よびぬれ面において，異 なる $T_{g}$ をつ $2 つ の S B R を$ 種々の割合でブレンドした SBRブレンドゴムの摩擦力を, それぞれ凝着の項とヒス テリシスの項にわけて考えることにより，ブレンドゴムの 摩擦特性と粘弾性特性との関係について明らかにすること を目的とした。また，カーボンブラックを配合した時と， シリカを配合した時の効果についても合わせて検討した.

\section{2. 実験装置および試料}

摩擦力は, ピンーディスク型摩擦試験機を用いて測定し, その概略図を Fig.1に示した。この装置は，ピンホルダー (1)に取り付けたゴム試料とデイスク (3)上に取り付けた金網 (2)とを摩擦させる試験機であり, 実験中に発生する摩擦力 は，平行ばね(6に取り付けたひずみゲージ(5)で測定した。 ゴム試料は, 厚さ $2 \mathrm{~mm}$, 底辺 $4 \mathrm{~mm}$ 角の柱状とし, あらか じめ耐水研摩紙 $c c \# 1500$ と摩擦し, 当り出しを行った。

実験は, $23{ }^{\circ} \mathrm{C}$ の室内で行い, 試験片にかかる荷重は $1.6 \mathrm{~N}$ とした。滑り速度は， $0.1 \mathrm{~mm} / \mathrm{s}$ から $200 \mathrm{~mm} / \mathrm{s}$ の範囲 


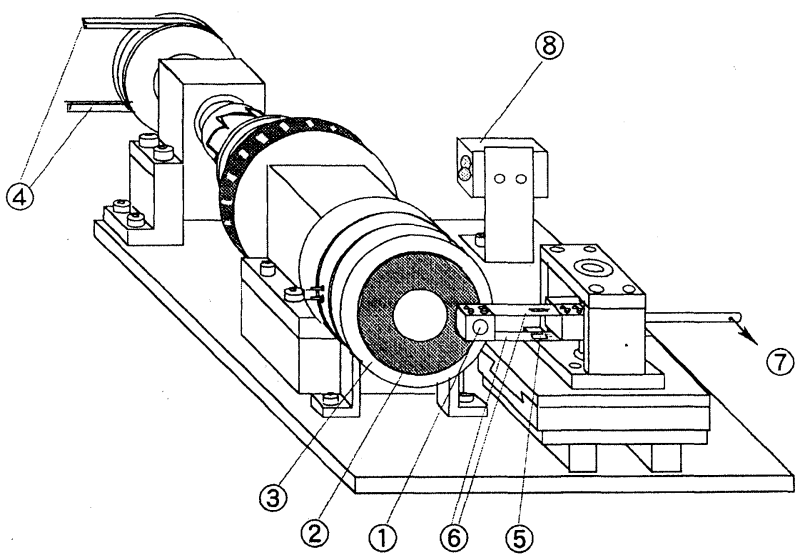

Fig.1 A pin-on-disk type tribometer :

(1) rubber specimen attached to the specimen holder,

(2) metal gauze, (3) disk, (4) driving belt, (5) strain gauge,

(6) parallel leaf spring, (7) dead weight, (8) speed-meter.

で変化させた

相手面には，JIS G335に規定された TW-Sで示される ステンレス鋼線製綾織金網の\#250を使用した。ステンレ ス鋼線の線径は $40 \mu \mathrm{m}$ で, $25.4 \mathrm{~mm}$ の間に 250 個の格子を もっている．金網は規則的な突起を有するために，摩擦の ヒステリシスの項に対する考察が容易である.

Fig.2にステンレス金網とゴムとの接触状況を示した。

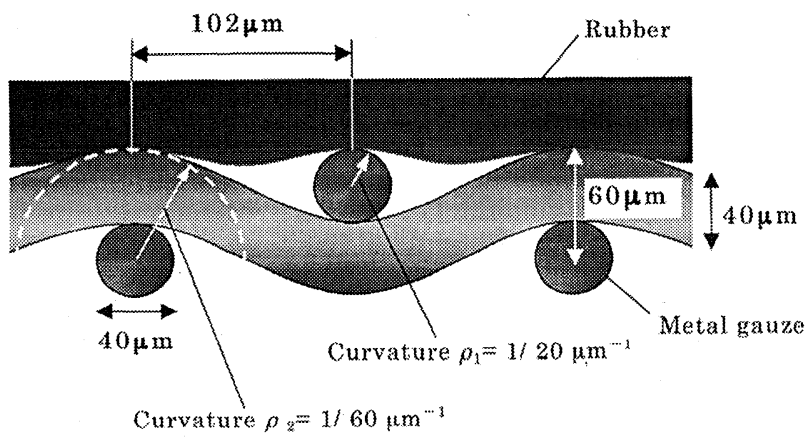

Fig.2 Contact of rubber on metal gauze
ゴムと金網の接触面は，短軸の曲率が $1 / 20 \mu \mathrm{m}^{-1}$, 長軸の 曲率が $1 / 60 \mu \mathrm{m}^{-1}$ の回転だ円体の表面と見なすこととし た。 また，突起間の距離は，鋼線に平行な方向で $102 \mu \mathrm{m}$, 鋼線に対して $45^{\circ}$ の方向で $143 \mu \mathrm{m}$ であり, 摩擦軌道上の 平均の突起間距離は，ほぼ $120 \mu \mathrm{m}$ となる。この金網上を 滑るゴムの変形周波数 $\omega(\mathrm{Hz})$ は，ゴムの滑り速度をv $(\mathrm{mm} / \mathrm{s})$ とし, 平均突起間距離 $L(\mathrm{~mm})$ を鋼線に平行な方 向と $45^{\circ}$ 方向の突起間距離の平均値としたとき,

$$
\omega=v / L=8.1 v
$$

と，書ける.

ぬれ面の測定は，このステンレス金網にシリコーンオイ ルを塗布した状態で実施した。 シリコーンオイルは，東レ ダウコーニングシリコーン社製 $\mathrm{SH} 200$ の動粘度が $1 \mathrm{~mm}^{2} / \mathrm{s}$ のものを使用した. シリコーンオイルは定期的に塗布し，

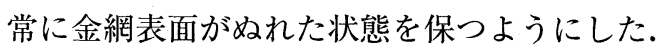

粘弾性試験は，粘弾性スペクトロメーター（上島製作所 (株製)を用い，周波数および温度を変量して測定した。ゴ ム試料に $1 \%$ の伸長ひずみを静的に与えた状態で $\pm 0.2 \%$ の 動ひずみを与えた. 動ひずみの周波数を $1 \mathrm{~Hz}$ から $90 \mathrm{~Hz}$ ま で $5 \mathrm{~Hz}$ 間隔で変化させ，温度は $-7{ }^{\circ} \mathrm{C}$ から $48{ }^{\circ} \mathrm{C}$ まで $5{ }^{\circ} \mathrm{C}$ 間 隔で測定した．得られた各測定温度の粘弾性の周波数分散 を水平方向にシフトし， $23{ }^{\circ} \mathrm{C}$ の曲線に重ね合せることで マスターカーブを得た。このマスターカーブを粘弾性特性 值とした。

ゴム試料としては，Table 1 に示すように， $T_{g}$ がー $51{ }^{\circ} \mathrm{C}$ と $-6{ }^{\circ} \mathrm{C}$ の 2 種類のゴム SBR-1, SBR-2を用い, そのブ レンド比率を 0 〜 100phr まで5水準に変量した。 また，そ れぞれにカーボンあるいはシリカを配合した合計 10 種類 のゴム試料を，摩擦試験，粘弾性試験に供した。

Fig.3 (a) (b) (c) は，SBR-1 と SBR-2 とをそれぞれ75 : 25，50:50，25:75の比率でブレンドした無充てんゴムの 透過型電子顕微鏡写真である. Fig.3 (a)〜 (c)のいずれの

Table 1 Compound formulations (phr)

\begin{tabular}{|c|c|c|c|c|c|c|c|c|c|c|}
\hline Specimen No. & $\begin{array}{c}1 \\
100 / 0- \\
\text { Carbon }\end{array}$ & $\begin{array}{c}2 \\
75 / 25- \\
\text { Carbon } \\
\end{array}$ & $\begin{array}{c}3 \\
50 / 50- \\
\text { Carbon }\end{array}$ & $\begin{array}{c}4 \\
25 / 75- \\
\text { Carbon }\end{array}$ & $\begin{array}{c}5 \\
0 / 100- \\
\text { Carbon } \\
\end{array}$ & $\begin{array}{c}6 \\
100 / 0- \\
\text { Silica } \\
\end{array}$ & $\begin{array}{c}7 \\
75 / 25- \\
\text { Silica } \\
\end{array}$ & $\begin{array}{c}8 \\
50 / 50- \\
\text { Silica }\end{array}$ & $\begin{array}{c}9 \\
25 / 75- \\
\text { Silica } \\
\end{array}$ & $\begin{array}{l}10 \\
0 / 100 \\
\text { Silica }\end{array}$ \\
\hline $\begin{array}{l}\text { SBR-1 } 1\left(T_{g}=-51{ }^{\circ} \mathrm{C}\right) \\
\text { SBR-2 }\left(T_{g}=-6{ }^{\circ} \mathrm{C}\right)\end{array}$ & 100 & $\begin{array}{l}75 \\
25 \\
\end{array}$ & $\begin{array}{l}50 \\
50 \\
\end{array}$ & $\begin{array}{l}25 \\
75 \\
\end{array}$ & 100 & 100 & $\begin{array}{l}75 \\
25 \\
\end{array}$ & $\begin{array}{l}50 \\
50 \\
\end{array}$ & $\begin{array}{l}25 \\
75 \\
\end{array}$ & 100 \\
\hline $\begin{array}{l}\text { N339 black } \\
\text { Silica } \\
\text { Coupling agent } * 1 \\
\text { Diethylene glycol }\end{array}$ & 90 & 90 & 90 & 90 & 90 & $\begin{array}{c}90 \\
9 \\
6 \\
\end{array}$ & $\begin{array}{c}90 \\
9 \\
6 \\
\end{array}$ & $\begin{array}{c}90 \\
9 \\
6 \\
\end{array}$ & $\begin{array}{c}90 \\
9 \\
6 \\
\end{array}$ & $\begin{array}{l}90 \\
9 \\
6 \\
\end{array}$ \\
\hline $\begin{array}{l}\mathrm{ZnO} \\
\text { Stearic acid } \\
\text { Anti oxidant } * 2\end{array}$ & $\begin{array}{l}3 \\
1 \\
1\end{array}$ & $\begin{array}{l}3 \\
1 \\
1\end{array}$ & $\begin{array}{l}3 \\
1 \\
1\end{array}$ & $\begin{array}{l}3 \\
1 \\
1\end{array}$ & $\begin{array}{l}3 \\
1 \\
1\end{array}$ & $\begin{array}{l}3 \\
1 \\
1\end{array}$ & $\begin{array}{l}3 \\
1 \\
1\end{array}$ & $\begin{array}{l}3 \\
1 \\
1\end{array}$ & $\begin{array}{l}3 \\
1 \\
1\end{array}$ & $\begin{array}{l}3 \\
1 \\
1\end{array}$ \\
\hline Process oil & 50 & 50 & 50 & 50 & 50 & 60 & 60 & 60 & 60 & 60 \\
\hline $\begin{array}{l}\text { Accelerator } \mathrm{CZ}^{* 3} \\
\text { Accelerator } \mathrm{DPG} * 4 \\
\text { Sulfur }\end{array}$ & 1.5 & 1.5 & 1.5 & 1.5 & 1.5 & $\begin{array}{l}1.5 \\
0.5 \\
2.0\end{array}$ & $\begin{array}{l}1.5 \\
0.5 \\
2.0\end{array}$ & $\begin{array}{l}1.5 \\
0.5 \\
2.0\end{array}$ & $\begin{array}{l}1.5 \\
0.5 \\
2.0\end{array}$ & $\begin{array}{l}1.5 \\
0.5 \\
2.0\end{array}$ \\
\hline
\end{tabular}

*1 Bis-(3-triethoxisilylpropyl)-tetrasulfide

${ }^{* 2} N$-1,3-Dimethylbutyl- $N$-paraphenylenediamine

${ }^{* 3} \mathrm{~N}$-Cyclohexyl-2-benzothiazyl sulfeneamide

${ }^{* 4}$ 1,3-Diphenyl guanidine 
(a)

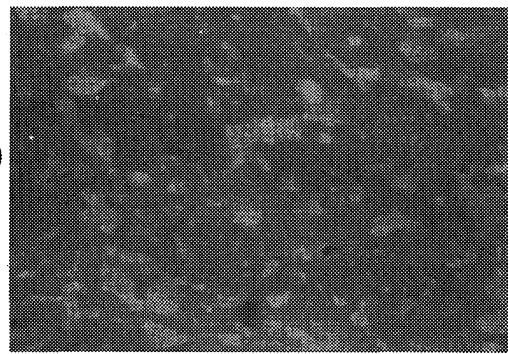

(b)

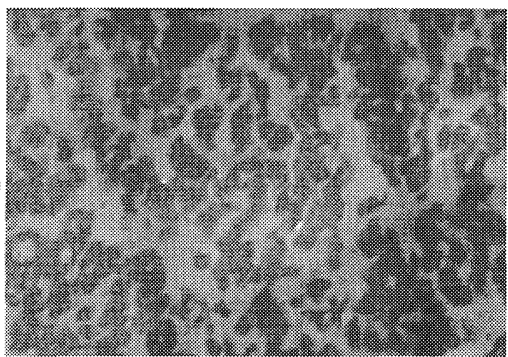

(c)

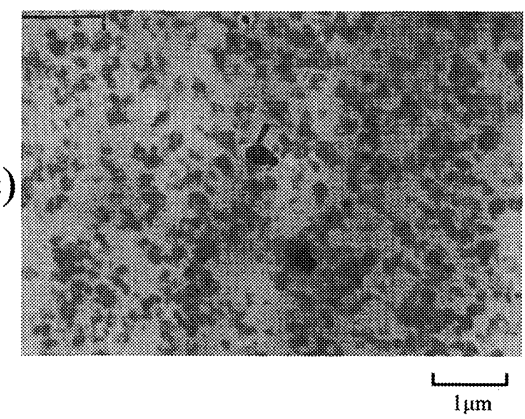

Fig.3 Morphology of unfilled SBR blends :(a) SBR-1 : SBR-2 $=75 / 25$, (b)SBR $-1: \mathrm{SBR}-2=50 / 50$, (c) SBR $-1: \mathrm{SBR}-2=25 / 75$.

(a)

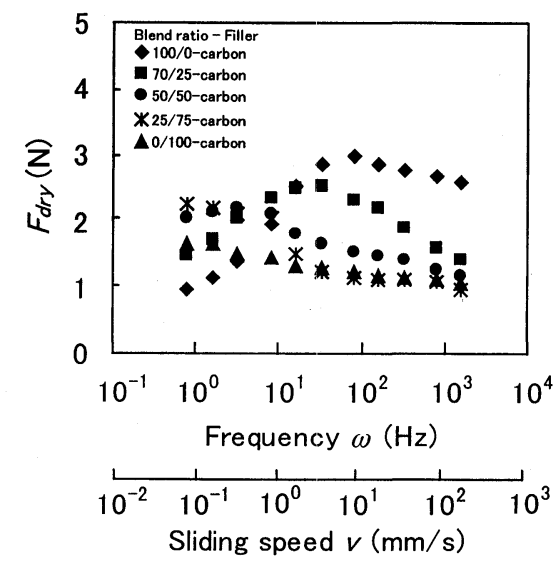

( b )

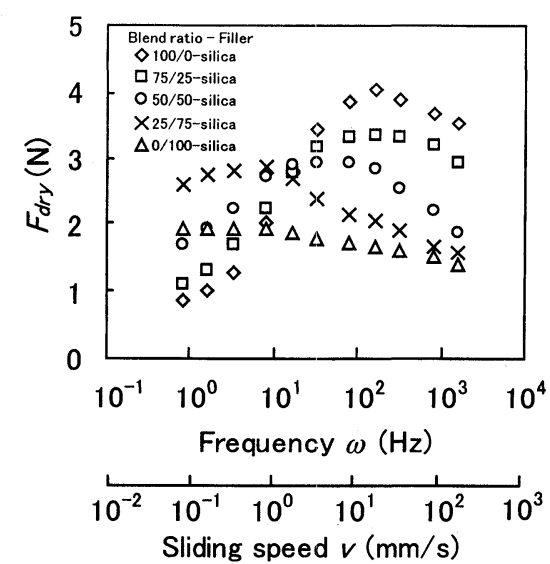

Fig.4 Variations in the friction force rubbed against the dry metal gauze with frequency or sliding speed :(a) carbon black-filled SBR blends, (b) silica-filled SBR blends.
写真においても $\mathrm{SBR}-1$ と SBR-2が相溶しないことがわか る.ブレンド比率から, 黒い相が $\mathrm{SBR}-1$, 白い相が SBR2である.

\section{3. 結果}

\section{1 ブレンドゴムの乾燥面との摩擦}

乾燥面におけるブレンドゴムの摩擦力 $F_{d r y}$ と滑り速度 $v$

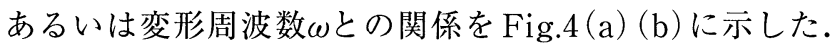
Fig.4 (a) (b)に示すように，乾燥面におけるブレンドゴム の摩擦力は，滑り速度あるいは変形周波数に対して 1 つの ピークをもった．そのピークは， $T_{g}$ が高い SBR-2のブレ ンド比率を増やすことで低速度側に移動し，ピーク值が低 下した．同一ポリマーに対するカーボン配合ゴムとシリカ 配合ゴムの比較では，シリカ配合ゴムの方が，摩擦力が高 い傾向が見られた。

\section{2 ブレンドゴムのぬれ面との摩擦}

ぬれ面におけるブレンドゴムの摩擦力 $F_{w e t}$ と滑り速度 $v$ あるいは変形周波数いとの関係を Fig.5 (a) (b)に示した。 ぬれ面におけるブレンドゴムの摩擦力も，滑り速度あるい は変形周波数に対して 1 つのピークをもつが，乾燥面の $F-v$ 特性のようにピーク位置やピーク值とブレンド比率 との間に一定の傾向が見られなかった。また，乾燥面にお
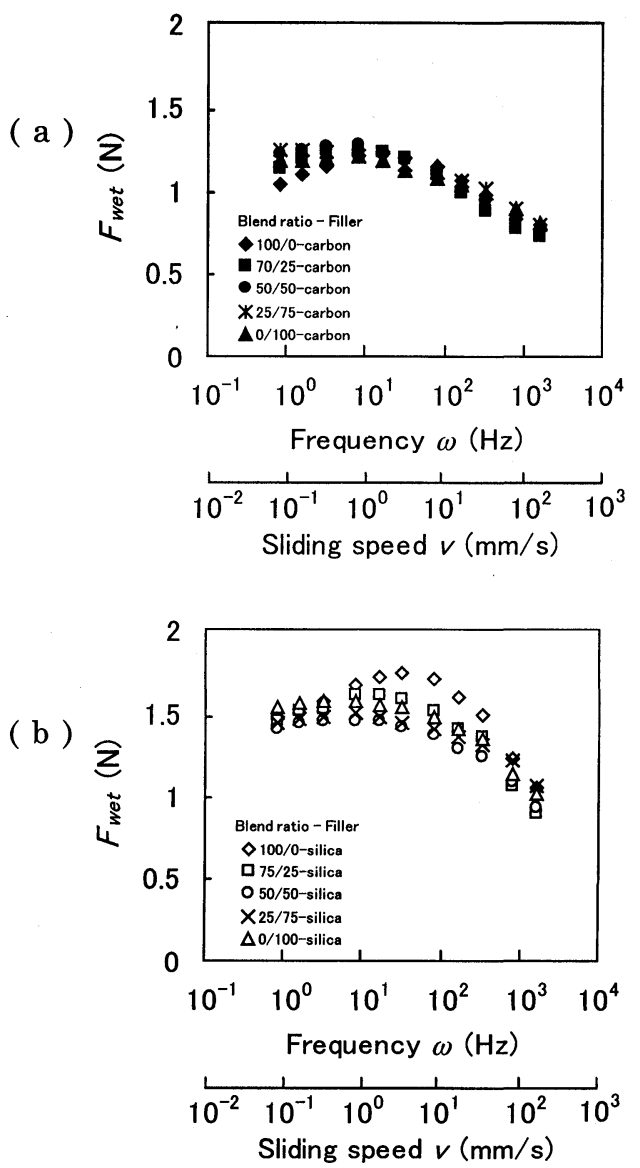

Fig.5 Variations in the friction force rubbed against the wet metal gauze with frequency and sliding speed :(a)carbon black-filled SBR blends, (b) silica-filled SBR blends. 
ける摩擦力に比べて試料間の差が小さかった. カーボン配 合ゴムとシリカ配合ゴムの比較では，ぬれ面においてもシ リカ配合ゴムのほうが，摩擦力が高い傾向が見られた。

( a )

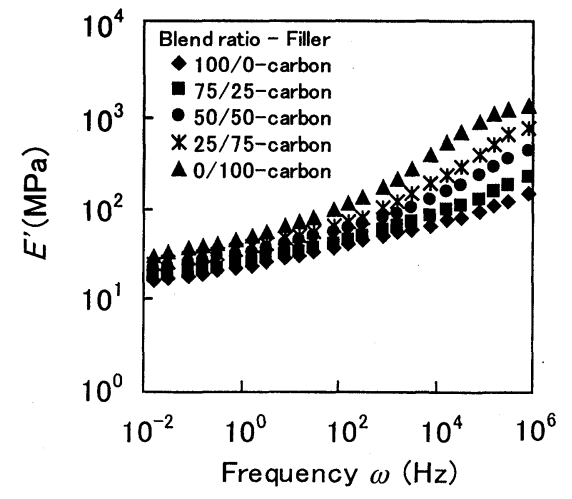

( b )

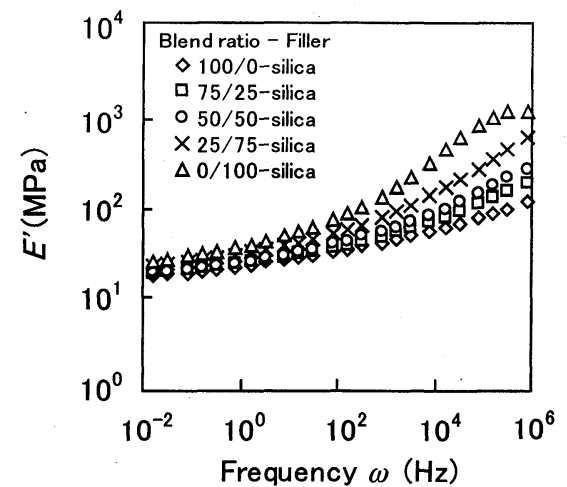

Fig.6 Frequency dependence of storage modulus $E^{\prime}$ : (a) carbon black-filled SBR blends, (b) silica-filled SBR blends.

(a)
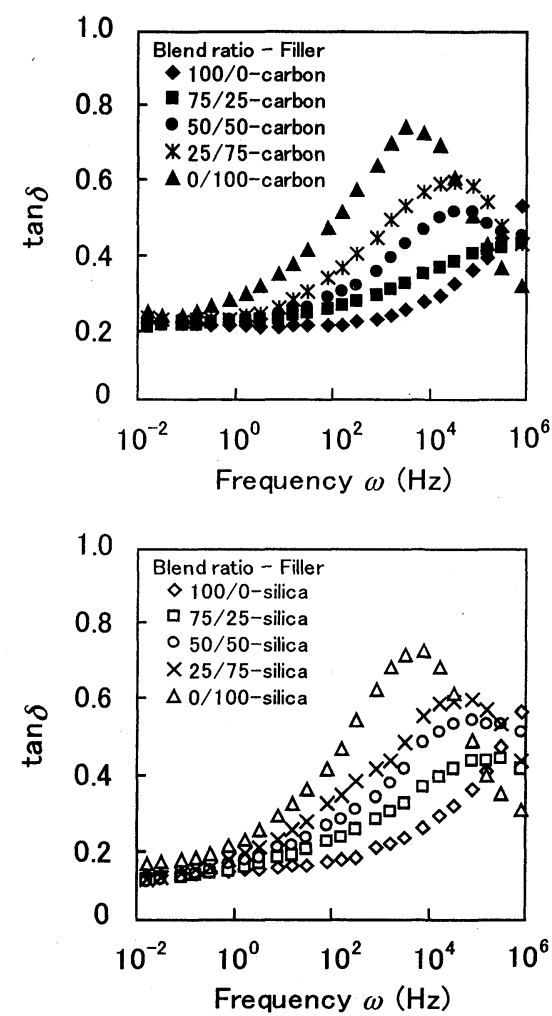

Fig.7 Frequency dependence of $\tan \delta$ : (a) carbon black-filled SBR blends, (b) silica-filled SBR blends.

\section{3 各種ブレンドゴムの物理的性質}

$23^{\circ} \mathrm{C}$ における各試料の貯蔵弾性率 $E^{\prime}$ の周波数依存性を Fig.6(a). (b)に示した. Fig.6(a)（b)に見られるように， SBR-2のブレンド比率が増えるに従って，E’が増加した.

同様に, $23^{\circ} \mathrm{C}$ における各試料の損失正接 $\tan \delta$ の周波数 依存性を Fig.7(a) (b)に示した. Fig.7(a) (b)に示すように， $\mathrm{SBR}-2$ の試料およびSBR-2 を含むブレンド試料では，実 験を行った周波数の範囲に1つのピークが見られた。その ピークは，SBR-2のブレンド比率を増やすことで低周波 数側に移動し，また，ピーク值が増加した。

\section{4. 考察}

\section{1 摩擦の凝着の項とヒステリシスの項}

前報 ${ }^{1)}$ において，乾燥したステンレス金網とゴムの摩 擦力を測定し, 摩擦力 $F$ は, 凝着の項 $F_{A}$ とヒステリシス の項 $F_{H}$ の和によって表されると考え, 接触面積 $A$, ゴム のせん断強さ $s, E ;, \tan \delta に よ り$ 次式で表されることを明 らかにした。

$$
\begin{aligned}
& F_{A}=A s \\
& F_{H}=k E^{,-1 / 3} \tan \delta \\
& F=A s+k E^{,-1 / 3} \tan \delta
\end{aligned}
$$

定数 $\mathrm{k}$ の值は, 式(5)を以下のように変形して,

$$
\frac{F}{A}=s+\frac{k E^{,-1 / 3} \tan \delta}{A}
$$

$F / A$ と $E^{-1 / 3} \tan \delta / A$ の゚ロットの勾配を求めれば良い。こ こで, $F / A$ と $E^{\prime-1 / 3} \tan \delta / A$ が線形関係となるためには， $s$ の值が一定值でなければならない。そこで，sの速度依存

( a )

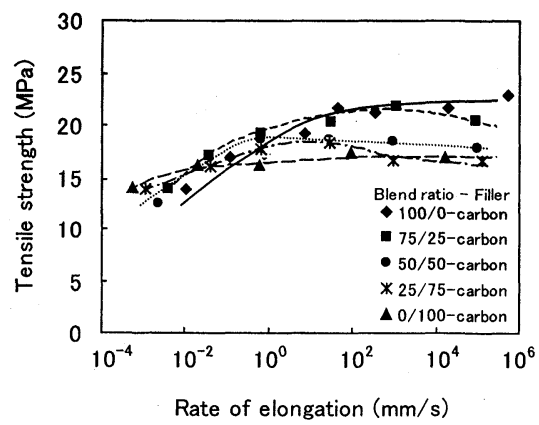

( b )

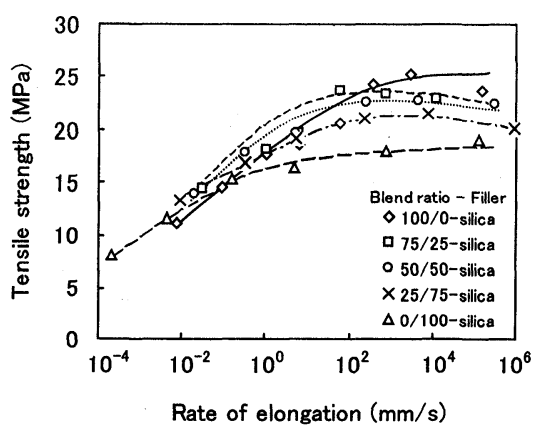

Fig.8 Variations in the tensile strength with rate of elongation : (a) carbon black-filled SBR blends, (b) silica-filled SBR blends. 


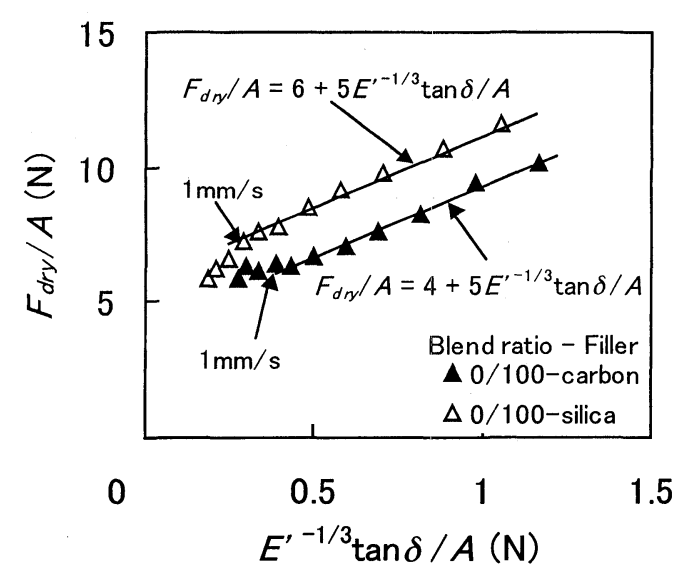

Fig.9 The relationship between $F_{d r y} / A$ and $E^{,-1 / 3} \tan \delta / A$

性を調べるために，引張強さの伸長速度依存性を測定し Fig.8(a) (b)に示した. 引張試験では，JIS K6251に基づき， 伸長速度を $500 \mathrm{~mm} / \mathrm{min}(8.33 \mathrm{~mm} / \mathrm{s})$ とし，伸長速度を変化 させるかわりに， $-10{ }^{\circ} \mathrm{C}$ から $100{ }^{\circ} \mathrm{C}$ まで温度を変化させて 測定を行った？その結果を Fig.5，6に示したマスターカー ブを作成する際のシフトファクターに従って温度 $23^{\circ} \mathrm{C} に$ おける伸長速度依存性に換算した.ゴムをブレンドしてい ない試料では, 高速度側で引張強さが一定となった。一方, ブレンドゴムの引張強さは伸長速度に対してピークを持 ち，引張強さが一定となる領域がなかった。そこで，SBR -2 の試料の $E, \quad \tan \delta$ および乾燥面における摩擦力 $F_{d r y}$ を 用いて， $F_{d r y} / A$ と $E^{\prime-1 / 3} \tan \delta / A$ とをプロットし，Fig.9に

(a)
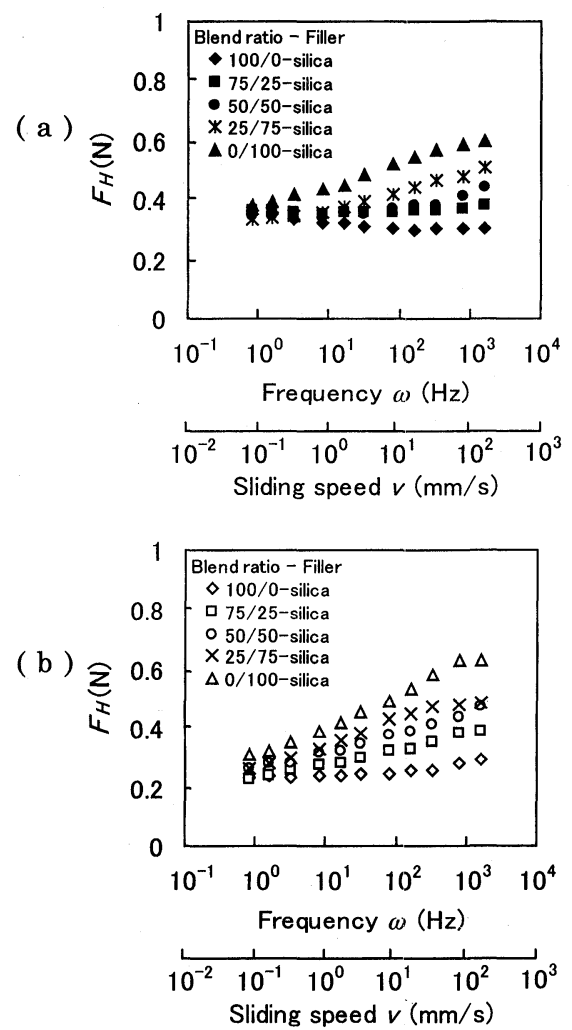

Fig.10 The hysteresis component of friction as a function of frequency : (a) carbon black-filled SBR blends, (b) silica-filled SBR blends.
示した. $F_{d r y} / A$ と $E^{,-1 / 3} \tan \delta / A$ は線形関倸にあり, 滑り速 度が $1 \mathrm{~mm} / \mathrm{s}$ 以上に相当する範囲で，勾配 $k$ は 5 であった。 勾配 $k$ の值が, 前報1) で得られた值 $(k=3)$ と異なる理由は,

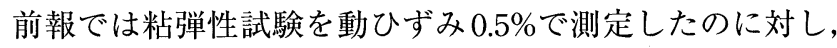

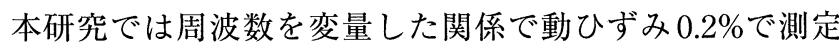
したためである。動ひずみが小さいほうがペイン効果 ${ }^{9)}$ により $E^{\prime}$ が大きくなり，それに伴って $\tan \delta か ゙$ 低下するた めに， $F_{H}$ が小さく見積もられる，その結果 $F_{H}$ の係数 $k$ は, 前報1)より大きな值となった。

\section{2 ブレンドゴムの摩擦に及ぼす $F_{H}$ の寄与}

上記の結果から，式(4)の $k$ の值を 5 とし，Fig.6 と Fig.7 のデータを用いて, 摩擦力のヒステリシスの項 $F_{H}$ を計算 しFig.10 (a) (b)に示した.ヒステリシスの項が，金網の凹 凸により変形するゴムのヒステリシスロスに起因するもの であるならば，乾燥面上をゴムが滑る時のヒステリシスの 項も，ぬれ面上をゴムが滑る時のヒステリシスの項もほほ 同じと考えられる.

Fig.10 (a) (b)によれば，SBR-2のブレンド比率を増や すと，実験を行った滑り速度の範囲で $F_{H}$ が増加した．特 に高速度域で増加の幅が大きかった。シリカ配合ゴムとカ 一ボン配合ゴムの比較では，低速度側ではシリカ配合ゴム の方が $F_{H}$ が低く，高速度側ではほとんど差がなかった。
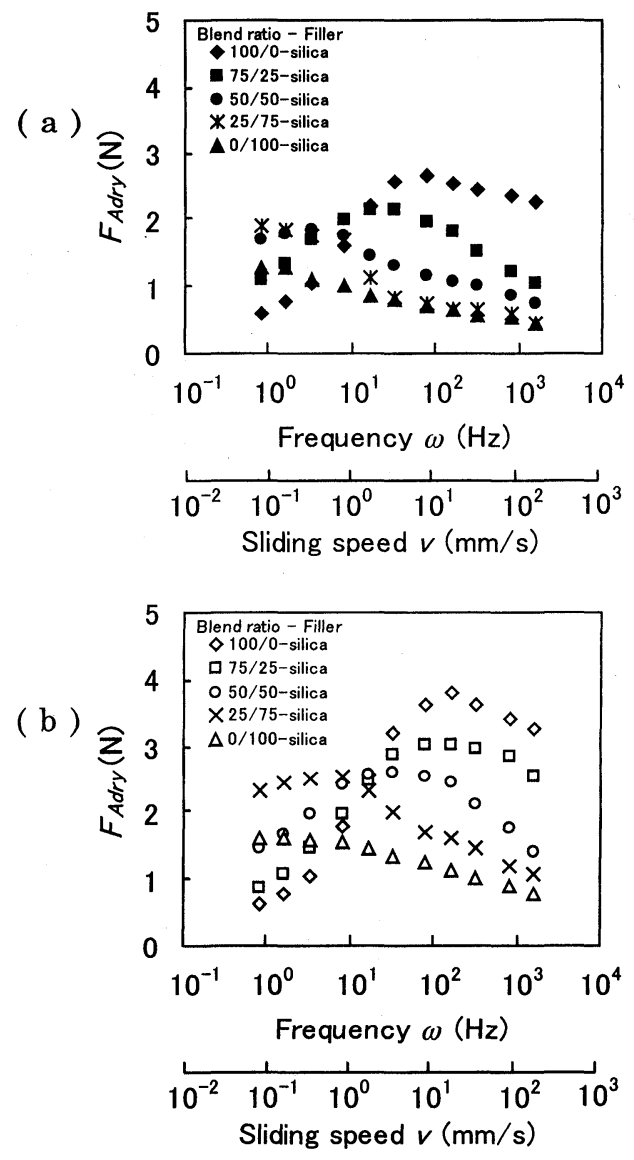

Fig.11 The adhesion component of friction rubbed against the dry metal gauze as a function of frequency : (a)carbon blackfilled SBR blends, (b) silica-filled SBR blends. 


\section{3 ブレンドゴムの摩擦に及ぼす $F_{A}$ の寄与}

一方, 式(5)に従って, Fig.4 およびFig.5に示した摩擦 力 $F_{d r y}, F_{\text {wet }}$ から Fig.10の $F_{H}$ を引くことにより, 乾燥面お よび好面に扔ける摩擦の凝着の項 $F_{\text {Adry }}, F_{\text {Awet }}$ を求め, Fig.11，12に示した.Fig.11(a)はカーボン配合ゴム, Fig.11(b) はシリカ配合ゴムの $F_{\text {Adry }}$ を示し, Fig.12(a)はカ 一ボン配合ゴム, Fig.12(b)はシリカ配合ゴムの $F_{\text {Awet }}$ を示 している.

Fig.11(a) (b)に示すように, $F_{A d r y}$ は測定した滑り速度の 範囲で1つのピークをもった。そのピークは, SBR-2の ブレンド比率の増加とともに低速度側に移動し，ピーク值 が低下した．また，シリカ配合ゴムのほうが， $F_{A d r y}$ のピー クが高速度側に見られ，ピーク值が高かった。

Fig.12 (a) (b)に示すように， $F_{\text {Awet }}$ は測定した滑り速度の 範囲で1つのピークをもち, そのピークはSBR-2のブレ ンド比率の増加とともに, 低速度側に移動した. シリカ配 合ゴムは，カーボン配合ゴムに比べ $F_{\text {Awet }}$ が高かった。 ま た， $F_{\text {Adry }}$ と比較すると， $F_{\text {Awet }}$ は大幅に低い值を示した。

このように，試料間の差は小さくなるものの，摩擦の凝 着の項は，ぬれ面においても乾燥面と同様の傾向が見られ た。ぬれ面においては潤滑膜によってゴムと路面との接触 が妨げられるが，部分的に固体接触しており，乾燥面と同

( a )

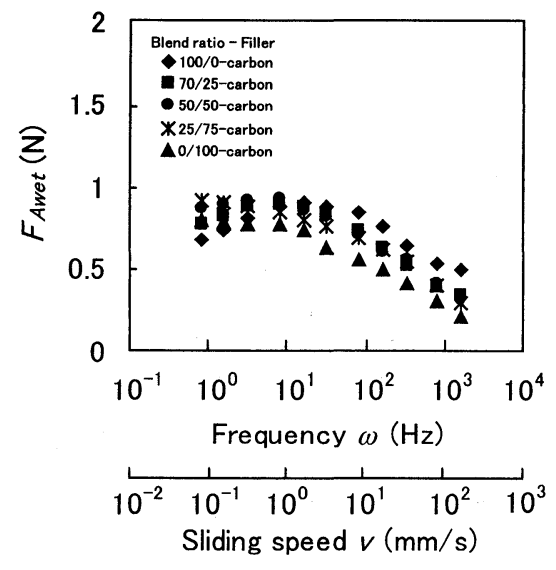

( b )

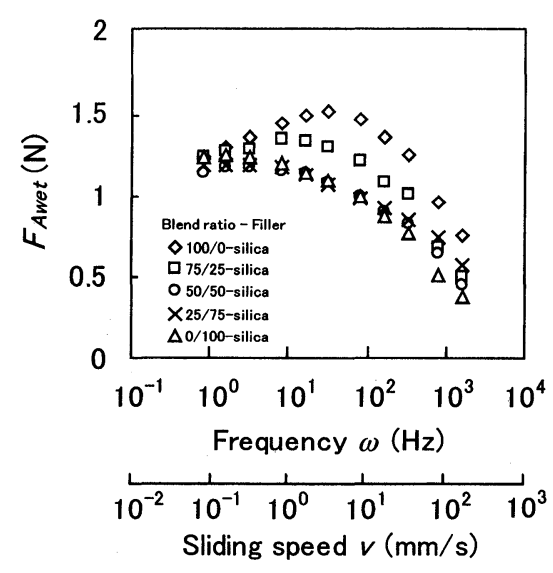

Fig.12 The adhesion component of friction rubbed against the wet metal gauze as a function of frequency : (a) carbon blackfilled SBR blends, (b) silica-filled SBR blends.
様に摩擦の凝着の項が寄与するものと考えられる。試料間 の差が小さくなるのは，固体接触する面積が低下するため と考えられるが，依然としてシリカ配合ゴムはカーボン配 合ゴムに比べて $F_{\text {Awet }}$ が高かった。

\section{4 界面におけるせん断強さ}

次に, 式(3)あるいは式(5)のせん断強さ $s$ と Fig.8に示 した引張強さとの関係について考察する。 せん断強さ $s$ は, 式(5)を変形した次の式から求められる.

$$
s=\frac{F}{A}-\frac{k E^{,-1 / 3} \tan \delta}{A}
$$

式(7)から求めたせん断強さ $s$ の滑り速度依存性を Fig.13(a) (b)に示した.ブレンドしていないゴムの $s$ は高速度側で ほぼ一定の值となるが，ブレンドゴムの $s$ は滑り速度に対 して1つのピークをもった.この傾向は, Fig.8(a) (b)に 示した引張強さの伸長速度依存性と類似している。また， Fig.13 (a) (b) とFig.8 (a) (b)は, 高速度側での各試料間の 大小関係, 更に速度の減少に伴いその関係が逆転する様が ほぼ一致している。このように, せん断強さ $s$ と引張強さ が類似の傾向を示した. したがって，2種類のSBRをブレ ンドした場合でも, 凝着の項は, 接触面積 $A$ とゴムの強度 の積によって説明される.

(a)
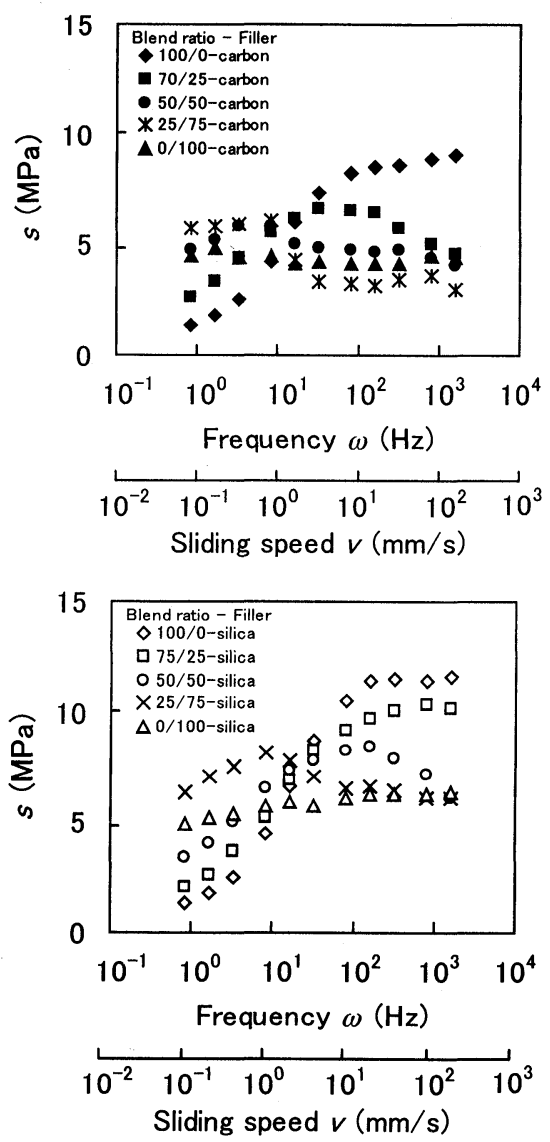

Fig.13 Variations in the shear strength with sliding speed : (a) carbon black-filled SBR blends, (b) silica-filled SBR blends. 
5. 結

論

ガラス転移温度 $T_{g}$ が $-51{ }^{\circ} \mathrm{C}$ と $-6{ }^{\circ} \mathrm{C}$ の互いに相溶しな い2種類のSBRを，各種割合でブレンドしたカーボン配合 ゴムおよびシリカ配合ゴムを用い，摩擦特性を調べた。金 網と各種ブレンドゴムとの摩擦力と滑り速度の関係を乾燥 状態およびぬれた状態で実験を行い，摩擦に及ぼすブレン ドの効果や補強剤の影響について調べた結果，以下の結論 を得た。

1）乾燥面におけるブレンドゴムの摩擦力の凝着の項は, 滑り速度に対して各々1つのピークをもち，そのピー クは $T_{g}$ の高い SBR-2のブレンド比率の増加に伴って 低速度側に移動し，また，ピーク值が低下した。

2 ) 湎と摩擦したブレンドゴムの摩擦の凝着の項は, 潤滑膜の存在によってその值が低下し，試料間の差が 小さくなるが，ブレンド比率による変化では乾燥面と ほぼ同じ傾向が見られた。

3 ) 摩擦のヒステリシスの項は， $T_{g}$ が高いほうのSBRの ブレンド比率の増大に伴い実験を行ったすべり速度の 範囲で増加した。
4 ）シリカ配合ゴムはカーボン配合ゴムに比べ，摩擦の凝 着の項のピーク值が高かった。一方，ヒステリシスの 項は，低速度側ではシリカ配合ゴムのほうが低く，高 速度側ではほとんど差がなかった。シリカ配合ゴムは カーボン配合ゴムに比べて凝着の項が高いため, 実験 を行ったすべり速度の範囲で摩擦力が高い值を示し た。

\section{参考 文 献}

1) 網野直也，内山吉隆，岩井智昭：日ゴム協誌，74, 110 (2001)

2) Ouyang, G. B., Tokita, N., Shieh, C.-H. : 143rd ACS Rubber Division Meeting, Denver, No.15(1993)

3 ) Veith, A. G. : Rubber Chem. Technol., 69, 654(1996)

4) Nahmias, M., Serra, A. : Rubber World., 218, 38(1997)

5) Mouri, H., Akutagawa, K. : 153rd ACS Rubber Division Meeting, Indianapolis, No.19 (1998)

6 ) Grosch, K., Heinz, M. : IRC2000 Rubber Conference, Helsinki, Finland (2000)

7 ) Hess, W. M., Klamp, W. K. : Rubber Chem. Technol, 56, 390(1983)

8 ) Takino, H., Inada, S., Okazaki, T., Sakashita, T. : 136th ACS Rubber Division Meeting, Detroit, No.36(1989)

9 ）秋山孝高：“カーボンブラック便覧(第 3 版)”カーボンブラック 協会編 (1995), p.448

\section{本会発行出版物ご案内}

（定価，会員価格はいずれも消費税別）

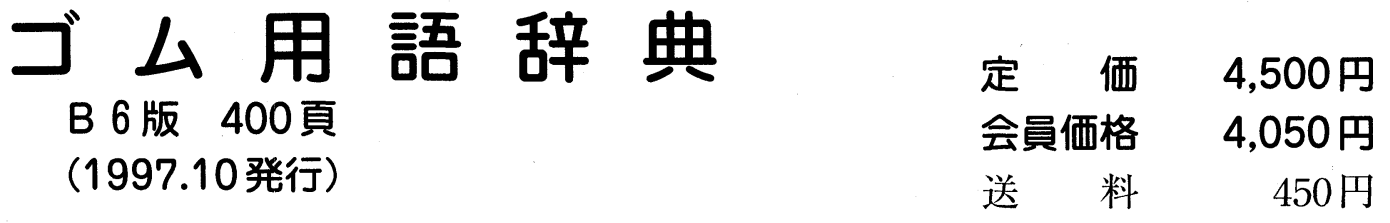

【ゴム産業に係わる技術用語, 製品用語を幅広く収録したものです。収録用語約 4,500 語.

* お申込の場合は，必要事項(送付先住所，勤務先，氏名，電話番号など)をご記入のうえ， FAXして下さい.

社団法人 日本ゴム協会 四書係あて

FAX 03 (3401) 4143 